may be and however great its concentrating power may be. We have seen that when exposed cold as soon as possible after ihe total phase of the eclipse, it was twenty-seven minutes after totality before the water lxiled. One-third of the sun was then uncovered. It is, therefore, reasonable to suppose that, if the eclipse had happened at noon, so that the first half of it could have been utilised as weil as the second half, the sun would have kept stean in the calorimeter, and it would have continued to distil until two-thirds of the sun's surface had been obscured. Then distillation, if it did not cease, would become so slow that its rate would have no value, and filty-four minutes would elapse before one-thircl of the sun would again be uncovered, during which the calorimeter would get cold. During this interval steam must be kept artificially. This is very easy. The glass tube which forms the steam dome is attached to a metal collar which screws down on a washer. It can, therefore, be easily detached. If, then, the steam tube of the calorimeter be connected by means of an india-rubber tube with a flask in which water is kept boiling, steam can be passed through the calorimeter at the normal rate until it is judged suitable to expose it again to the sun. There is no difficulty about this.

Although quite insignificant as a natural phenomenon, an annular eclipse is better for calorimetric experiments than a total one. On November 11,1901 , there will be an annular eclipse visible in Ceylon. The annular phase will last over ten minutes, and, at its greatest, 0.875 of the sun's disc will be covered. It is fairly certain that the calorimeter used in 1882 would not keep steam through this phase, but a larger reflector might be used. It would be worth while to have a reflector of such a size that steam would certainly be kept through the whole eclipse, especially during the annular phase, when all the radiation is from the peripheral region. J. Y. BLCHANAN.

\section{THE MINING STATISTICS OF THE WORLD}

$\mathrm{I}^{\mathrm{T}}$ is impossible to imagine a more concise, more intelligible, or more inexpensive collection of comparative mineral statistics than is contained in the (ieneral Report on Mines and Quarries prepared by Dr. C. Le Neve Foster for the Home Office, and it would be difficult to find an editor possessing in a more marked degree the requisite technical knowledge, literary skill and critical acumen for the difficult task of abstracting and collating the heterogeneous official mineral statistics of foreign countries and of rendering them intelligible to the general reader. In many countries the statistics published are imperfect or antiquated. Nevertheless, as regards output, Dr. Le Neve Foster has succeeded in getting together a mass of figures which, in the case of the more important minerals, may certainly be regarded as trustworthy. He has brought into one focus a representation of the present position of the mining industries of the world, and has thus rendered it possible to comprehend the enormous development that has taken place within recent years. The statistics given are of the greatest importance from a commercial point of view. In the United Kingdom alone the value of the minerals raised in 1899 was $97,470,000 l$, and the vast sums representing British capital invested in mines in all parts of the world will be readily appreciated. Some indication of the remarkable strides made by the mining industry during the past ten years is afforded by the following comparison of the world's output of metals in 1889 and in 1899 :-

\begin{tabular}{|c|c|c|c|c|}
\hline & & $\begin{array}{l}1889 \\
\text { Metric Tons }\end{array}$ & & $\begin{array}{c}18,9 \\
\text { Mctric } 2 \text { 'ons }\end{array}$ \\
\hline Iro & $\cdots$ & $26,000,000$ & $\cdots$ & $39,1,36,000$ \\
\hline & $\ldots$ & 182 & $\ldots$ & 477 \\
\hline & $\cdots$ & 3,900 & $\ldots$ & 5,44 \\
\hline & $\ldots$ & 266,000 & $\ldots$ & 507,000 \\
\hline & $\ldots$ & 549,000 & .. & 676,000 \\
\hline $\mathrm{Zi}$ & $\ldots$ & 335,000 & $\ldots$ & $5^{11}, 000$ \\
\hline Tir & $\ldots$ & 55,000 & $\ldots$ & 74,000 \\
\hline
\end{tabular}

In 1899 the world produced $723,239,000$ tons of coal, $16,755,000$ tons of petroleum, and $12,890,000$ tons of sait. Nearly one-third of the coal supply was furnished by the British Empire. The United States supplied nearly another third, and Germany more than a sixth. The remainder was contributed mainly by Austria-Hungary, France and Belgium. The coal production of the principal countries was as follow's :-

\begin{tabular}{|c|c|c|c|c|c|c|}
\hline \multirow{4}{*}{\multicolumn{2}{|c|}{$\begin{array}{l}\text { United States } \\
\text { United Kingdom } \\
\text { German Empire } \\
\text { Austria-Hungary }\end{array}$}} & & & & \multirow{2}{*}{\multicolumn{2}{|c|}{$\begin{array}{l}\text { Metric tons. } \\
\ldots \quad 230,254,000\end{array}$}} \\
\hline & & $\begin{array}{l}\ldots \\
\ldots\end{array}$ & $\begin{array}{l}\cdots \\
\ldots\end{array}$ & $\cdots$ & $\begin{array}{l}\cdots \\
\cdots\end{array}$ & \\
\hline & & $\ldots$ & $\ldots$ & $\ldots$ & $\ldots$ & I $35,824,000$ \\
\hline & & $\ldots$ & $\ldots$ & $\ldots$ & $\ldots$ & $37.562,000$ \\
\hline France & $\ldots$ & $\ldots$ & $\ldots$ & $\ldots$ & $\ldots$ & $31,218,000$ \\
\hline Belgium & $\ldots$ & $\ldots$ & $\cdots$ & $\ldots$ & $\ldots$ & $22,072,000$ \\
\hline Japan & $\ldots$ & $\ldots$ & $\ldots$ & $\ldots$ & $\ldots$ & $6,761,000$ \\
\hline India & & $\ldots$ & & $\ldots$ & $\ldots$ & $5,016,000$ \\
\hline New Sol & h Wales & & $\ldots$ & .. & $\ldots$ & $4,67 \mathrm{I}, 000$ \\
\hline Canada & $\ldots$ & $\ldots$ & $\ldots$ & $\ldots$ & $\ldots$ & $4,142,000$ \\
\hline Spain & $\ldots$ & $\ldots$ & $\ldots$ & $\ldots$ & $\ldots$ & $2,671,000$ \\
\hline Trangvaz & $\therefore$ & $\ldots$ & $\ldots$ & $\ldots$ & ... & $I, 938,000$ \\
\hline
\end{tabular}

In 1889 the United States for the first time outstripped Great Britain as a coal-producing country. In twelve months the British increase was $18,000,000$ tons, but that of the United States was $30,000,000$ tons. This enormous increase is undoubtedly due to the extended use of coal-cutting machinery. In the United States 23 per cent. of the total output of coal was mined by machinery. Only a little more than $1 \frac{1}{2}$ per cent. of the output was so obtained in Great Britain. The path of progress is, therefore, clearly indicated to British colliery owners.

As gold producers the British possessions take the first place, and, thanks to the increased output of Canada and of Western Anstralia, the British Empire reached a total of $5,475,000$ ounces, or more than one-third of the world's supply. Onefourth of the world's salt, and more than half of the tin, are produced by the British Empire. On the other hand, the production of copper, lead, petroleum, silver and zinc is small in comparison with the world's output. The magnitude of the petroleum industry is surprising in view of the fact that its growth has been within the last half of the nineteenth century. The chief producing countries were :- Russia with $8.340,000$ tons, the United States with 7,247,000 tons, Austria-Hungary with 325,000 tons, Roumania with $3 \mathbf{I}_{3}, 000$ tons, and the Dutch East Indies with 217,000 tons. The United States has had to cede to Russia the position it so long held as first in the production of petroleum.

In 1899 the Transvaal was the greatest gold-producing country of the world, the output representing a value of $16,273,000 \%$. Owing to the war, detailed statistics for 1899 are not available. In Cape Colony the outbreak of the war in October caused a rapid decrease in the output of the coal mines, and eventually stopped nearly all of them. In Natal, again, coal-mining was interfered with, and no official report for 1899 has been received. In Rhodesia, on the other hand, gold. mining made remarkable progress. The output of gold was 65,304 ounces in 1899 , whilst in the previous year it was 18,085 ounces. The mining prospects of the country are certainly very satisfactory, more especially as the search for coal is giving most promising results.

The copious references to original sources of information given by the editor in footnotes form a very valuable feature of the report. In this connection it is noticeable that in his capacity of juror at the Paris Exhibition I)r. Le Neve Foster has had access to numerous special reports which, but for his assiduity, would hardly have come to the knowledge of English engineers. The great development of the iron ore resources of Luxemburg during the last thirty.two years, for example, was clearly illustrated in a table shown at the Paris Exhibition. Ir. I868 the output of iron ore was 691,000 tons, whilst in 1899. it was 5,995,000 tons. At another place in the volume the latter figure is given as $6,014,000$ tons, there being apparently a slight discrepancy between the figures obtained by the Home Department of the Grand Duchy and by the German Customs Union, of which Luxemburg forms part. The political classification of the various States is in several cases a matter of difficulty, and has been attended to by Dr. Le Neve Foster. with scrupulous care. It is possible, however, that in dealing with Austria and Hungary under one heading, while Sweden and Norway are dealt with separately, he will cause offence to the ultra-patriotic Magyars. Since the compromise between the two States, renewable every ten years, was not renewed in 1897, the Union is merely personal through the Emperor and Apostolic King, and in order to make it evident that Hungary is not a vassal State, the official denomination of the AustroIungarian Monarchy is to be preferred to the term Austro. Hungarian Empire used in the report.

NO. I640, voL. 63] 
Although not so trustworthy as the figures relating to mineral output, the statistics of persons employed and of accidents in mines are quite as important. The number of persons em. ployed at mineral workings in 1899 throughout the world amounted to $4,312,000$, of which $1,635,000$ were engaged in the British Empire. The United Kingdom headed the list with 862,000 persons. Then followed Germany with 527,000 , the United States with 488,000 , France with 302,000 , Russia with 239,000, Austria-I Iungary with 219,000 , Belgium with 164,000 , and Japan with 133,000 . Prior to the war the late South African Republic employed ICO,000 miners. It appears that the British Empire employs more than one-third of all the persons engaged in mining and quarrying ir the world. It must, however, not be forgotten that published figures are far from being absolutely accurate, and those cited by Dr. Le Neve Foster are merely the best obtainable at the present time. As an example of inaccuracy, the official returns from Ceylon give $\mathrm{r}, 108,306$ persons employed in 1898 in mining in that island. It is incredible that the mining industry of Ceylon, which is comparatively insignificant as regards output, should afford occupation to as many persons as are employed in mining in all the other countries of the British Fmpire put together. Such figures are utterly useless for calculating death rates, and have, consequently, l,een discarded. The standard adopted for death rates is the number of persons killed per 1000 employed, and a comparison of the figures in different countries affords a good idea of the relative safety of the miner's occu. pation. In Great Britain, in 1899, there were killed in coal mines $1 \cdot 24$, in other mines, $1 \cdot 76$, in quarries $1 \cdot 19$, and in all mines and quarries 1.26 per 1000 employed. For the British Empire the average was I 27 for coal mines and I 64 for metal mines, and for the world $1 \cdot 83$ for coal mines and $1 \cdot 64$ for gold nines. In foreign countries the average was 2.25 in coal mines. It is evident, therefore, mining is conducted in Great Britain with a far smaller risk of accident to the workers than in most other countries. This gratifying result is due in no small measure to the untiring efforts made to improve the conditions of mining by means of legislation and covernment inspection. BENNETT H. BROUGH.

\section{THE MINERAL CONSTITUENTS OF DUST} AND SOOT FROM VARIOUS SOURCES. ${ }^{1}$

NORDENSKJÖLL collected and described three different kinds of dust, one consisted of diatoms, a second of a siliceous and apparently felspathic sand, both from the surface of the ice in Greenland ; while a third consisted of sooty-looking particles composed of elements invariably associated with iron meteorites and of uncommon occurrence in terrestrial matter, namely, besides metallic iron, cobalt, nickel, carbon, silicon and phosphorus. He concluded that it was meteoric matter showered down upon the earth, and that cosmic dust is falling imperceptibly and continually.

A great variety of mineral matters, including dust from various sources, having been examined spectrographically by the authors, they give an account of its composition. Specimens which fell from the clouds were compared with those from known terrestrial sources. The first comprised (I) solid matter forming the nuclei of hail-stones collected during a storm on April 14, 1897; (2) solid matter from hail and sleet collected during a heavy shower from $2.30 \mathrm{p} \mathrm{m}$. to 3 o'clock on March 28, I896; (3) pumice from the Krakatoa eruption of 1883 . These were examined for Prof. J. P. O'Reilly, who had collected them. (4) Dust from a dish exposed on November 16 and 17 , 1897 , in the outskirts of Dublin ; and other samples with a similar origin which had fallen into porcelain dishes placed on a grass-plat in a garden. Varieties of flue-dust, (4) from Crewe gas-works, (5) iron-works, (6) sulphuric acid works, and (7) copper-smelting works, (8) volcanic dust from three different sources, (9) soot from laundry, laboratory, kitchen and bedroom chimneys. Flue-dust is characterised by the larger proportions of lead, silver and copper than other varieties of dust and coal ashes contain. Nickel and manganese are notably present, but the most striking feature is the quantity of rubidium, gallium, indium and thallium in all samples. Volcanic dust shows the bands of lime and magnesia with strong spectra of the alkali metals, and these are evidently its leading basic constituents.

1 By Prof. W. N. Hartley, F.R.S., and Hugh Ramage. Abstract of a ead at a meeting of the Royal Society, february $2 \mathrm{r}$.

No. I640, vol. 63$]$
Soot is of variable composition, not so much with respect to the substances present as to the relative proportions of each in any two samples. Its larger proportion of lime distinguishes it from dust collected from the heavens. Nickel, manganese, copper, silver and lead are constant constituents. The presence of nickel is probably due to minute quantities of this element being disseminated in coal, which is first converted by the carbon monoxide produced in the fire into nickel tetracarbonyl, which is naturally volatile but subsequently becomes decomposed and nickel or nickel oxide is deposited.

Dust from the clouds, collected either by itself or in hail, snow, sleet or rain, exhilits a regularity in composition not seen in other varieties of dust. It contains, apparently, the same pro. portions of iron, nickel, calcium, copper, potassium and sodium. The chief difference occurs in dust suddenly precipitated in sleet, snow and hail, since lead is found in larger proportions in these, and particularly so in one specimen from sleet.

It is evident that the presence of nickel is not positive evidence that the dust from the clouds comes from other than a terrestrial source.

The dust which fell on November 16 and 17,1897 , with its similarity in composition to that of meteorites, its being attracted by the magnet and its appearance are quite in favour of its being of cosmic origin. On the other hand, in its composition it is unlike volcanic dust, flue-dust or soot.

\section{STUDIES IN VISUAL SENSATION}

$\mathrm{THE}$ object of these studies is to frame if possible a scale of visual sensation analogous to, and in correlation with, a scale of physical luminosity. The method is the employment of rotating discs.

If a disc be divided into eleven concentric areas of equal width, of which the inner is all white and the outer all black, while the intervęning areas have sectors giving a series of Io per cent. increments of white, this gives on rotation a series of grey rings between the black and white; but they are of very unequal values for sensation. While the step from black to the darkest grey involves a large stride in sensation, seemingly almost half-way towards the white, that from white to the lightest grey is of no great amount.

A contrast effect is very noticeable. Each grey annulus, especially in the darker rings, is differentiated in sensation into a darker moiety where it adjoins a lighter ring, and a lighter moiety when it adjoins a darker ring. But although contrast introduces a factor which somewhat distracts the judgment, the disturbance is not sufficient to invalidate the conclusion that equal, or approximately equal, increments of stimulus produce increments of brightness which differ widely in value.

By the use of slit discs on Maxwell's method the proportions of white stimulus may be so adjusted as to give, say, three rings intervening between white and black which do give approxim. ately equal sensation steps. It is somewhat difficult, however, to estimate their value, and contrast again introduces a disturbing element. We obtain only a first approximation to a scale of sensation. Taking the black employed (admittedly only a very dark grey and not an absolute black) as a zero, and calling the value of the white 100 per cent, both for sensation and stimulus, we have, on the arbitrary scale thus formed, the following percentages :-

\begin{tabular}{|c|c|c|c|c|c|c|c|}
\hline \multirow[b]{3}{*}{ Black ring } & & \multicolumn{3}{|c|}{ Sensation. } & \multicolumn{3}{|c|}{ Stimulus. } \\
\hline & & & acrement. & Sum. & & increment. & Sum. \\
\hline & & $\ldots$ & 0 & o & $\ldots$ & o & o \\
\hline Dark grey & $\ldots$ & $\ldots$ & 25 & 25 & $\ldots$ & 6.5 & 6.5 \\
\hline Mid grey & $\ldots$ & .. & 25 & 50 & $\ldots$ & 13.5 & 20 \\
\hline Light grey & $\ldots$ & $\ldots$ & 25 & 75 & $\ldots$ & 27 & 47 \\
\hline White ring & $\ldots$ & $\ldots$ & 25 & 100 & $\ldots$ & 53 & 100 \\
\hline
\end{tabular}

IIere the equal increments of sensation are correlated with increments of stimulus very nearly in geometrical progression.

By interpolation a smoothed curve can be drawn through the observed mid-point of 20 per cent. stimulus and translated on to a disc. But this does not give a smooth increase of sensa. tion from black to white through intervening greys. The value of the mid.point is too high.

Experiments with smoothed curves show that a mid-point of

1 Abstract of the Croonian Iecture delivered at the Royal Society on March 21 by Principal C. Lloyd Morgan, F.R.S. 